\title{
Controlling generation of family firms and earnings management in Indonesia: The role of accounting experts of audit committees
}

\author{
Edy Suprianto \\ Faculty of Economics and Business, Universitas Sebelas Maret \\ Indonesia \\ Faculty of Economics, Universitas Islam Sultan Agung \\ Indonesia

\section{Rahmawati Rahmawati} \\ Faculty of Economics and Business, UniversitasSebelasMaret \\ Indonesia
}

\section{Doddy Setiawan}

Faculty of Economics and Business, Universitas Sebelas Maret

Indonesia

\author{
Y. Anni Aryani \\ Faculty of Economics and Business, Universitas Sebelas Maret \\ Indonesia
}

Abstract. This study aims to identify whether the controlling generation (founder vs. descendant) of family companies in Indonesia affects earnings management and analyze the role of accounting experts of audit committees in minimizing the implementation of earnings management. A total of 258 samples are collected from manufacturing group companies listed in the 2012-2017 Indonesian stock

Indonesia exchange. A modified Jones model is used as a proxy for earnings management. Results reveal that controlling by the first generation negatively affects earnings management. Trend analysis results also show that family companies owned and managed by the first generation via earnings management remain stable for 6 consecutive years compared with that of family group companies owned and managed by the second generation. Accounting experts of audit committees negatively influence earnings management in family firms.

Keywords: accrual earnings management, family firms, controller generation companies, accounting experts of audit committees

\footnotetext{
Received:

January, 2019

1st Revision:

April, 2019

Accepted:

September, 2019

DOI:

10.14254/2071-

$8330.2019 / 12-3 / 21$
} 
JEL Classification: G30, M49

\section{INTRODUCTION}

Family companies in Indonesia have been investigated by numerous researchers, such as Prabowo (2013), Suyono (2016), and Diyanty (2017). Some of these studies have focused more on comparisons among family companies rather than non-family companies, but studies on different types of family companies have been rarely performed (Paiva et al., 2016).

Family companies are managed by a family with the goal of forming and pursuing a business vision held by all family members so that it can grow across generations of families (Chua et al., 1999). This description is consistent with the characteristics of family companies in Indonesia, that is, family members are involved in their company (PWC, 2014).

Maintaining a generation to work within a company has positive and negative effects. Some family companies try to sustain their business until the next generation and maintain good family names, such as the family owners of Djarum Group and Sinar Mas Group. Conversely, other family companies, such as PT Nyonya Meneer, maintain their business for succeeding generations but often encounter family conflicts that result in their destruction.

This research aims to analyze whether the earnings quality of a family company controlled by the first generation (founder) differs from that of a company dominated by the next generation (descendant). Further research has yet to be performed to show the relationship of family companies with earnings quality in Indonesia.

According to socio-emotional wealth (SEW) theory, family companies prioritize SEW rather than other interests. Gomez-Mejia et al. (2007) stated that business owners avoid risks to monitor their SEW, but other company owners take risks if the priority SEW becomes threatened. Family companies controlled by the first generation prioritize family interests, such as maintaining the good name of their family, over other interests by avoiding risky actions, such as earnings management, which can damage their reputations. The first generation or family founders have high family ties and assume that family priorities are more important than business objectives (Westhead, 2003). Gils et al. (2004) also found that when the second or third generation take control over a company, family priorities decrease.

The Capital Market Supervisory Agency (BAPEPAM) issued a Decree of the Chairman of BAPEPAM. Kep-29/PM/2004 to oblige companies listed on BEI to have an audit committee. According to agency theory, the role of an audit committee as a controlling party in preventing the opportunistic acts of management varies considerably. Abbott et al. (2004) indicated that an audit committee can increase the quality of financial statement restatement. Chandar et al. (2014) and Chen et al. (2007) showed that an audit committee can reduce earnings management. This research aims to examine whether an audit committee can minimize the implementation of earnings management in family firms based on SEW theory.

\section{LITERATURE REVIEW}

\subsection{Socio-emotional wealth (SEW) theory}

Gomez-Mejia et al. (2007) proposed SEW theory, which predicts that the owner of a family is "loss averse" and attaches importance to SEW. They take a risky decision to earn SEW, although it reduces its economic wealth. At the same time, they avoid risky decisions that may increase their economic wealth 
but can reduce SEW (Cennamo et al., 2012). According to Gomez-Mejia et al. (2007), an important aspect of the SEW of a family business is the fulfillment of needs related to family identification, such as family control and a good family name.

Family companies in Indonesia have been investigated on the basis of agency theory. Masripah et al. (1999) examined tax avoidance behavior carried out by family companies and found no tax evasion cases from companies controlled by family ownership. In contrast to the findings of Wirawan dan Diyanty (2014) and Muawanah (2014) who evaluated the governance of family companies compared with nonfamily companies, they concluded that the level of corporate governance used by the two groups of companies differs.

Since Gomez-Mejia et al. (2007) introduced SEW theory, three researchers, namely, Stockmans et al. (2010), Achleitner et al. (2014), and Pazzaglia et al. (2013), have analyzed the earnings quality of family companies based on SEW theory. In this theory, Gomez-Mejia et al. (2007) explained that family companies are motivated to implement earnings management because of non-economic goals, including family control and influence, family identity, closeness to social relations, emotional linkages, and maintaining family ties within the company through dynastic succession. Losing SEW means loss of spirit and status and even failure to meet family expectations.

\subsection{Family ownership and earnings management in Indonesia}

According to Law No. 40 of 2007 on Limited Liability Companies, alimited liability company's ("Company") organs consist of a general meeting of shareholders (GMS), a board of directors, and a board of commissioners. GMS has authority not given to the board of directors or the board of commissioners within the limits specified in this law and/or the articles of association. The board of directors should be a competent corporate body fully responsible for the maintenance of the Company for its interest in accordance with the purposes and objectives of the Company and to represent the Company both inside and outside the court in accordance with the provisions of the articles of association. The board of commissioners is the Company's organ that performs the general and/or specific supervision in accordance with the articles of association and gives advice to the board of directors (Widyaningsih et al., 2017).

This corporate organ in Indonesia follows a "two-tier board system," which is a company management system where parties that run a company are separated from those who oversee the running of the company. This system varies from a "one-tier system" applied to countries in the US and the UK, where company managers and supervisors work under one organ, that is, the board of directors (Wulandari, 2004). The position of a manager or a director within a company that follows a one-tier system is usually calleda chief executive officer. In Indonesia, according to Law No. 40 of 2007, a director, commonly referred to as president director, holds the highest managerial position.

Porta et al. (2002), Claessens et al. (2000), and Carney and Child (2013) stated that corporate ownership in Indonesia is largely controlled by families. This result is supported by Habib et al. (2017), who concluded that the pattern of ownership structure in Indonesia is more concentrated than wide spread. Mulyani et al. (2016) added that companies listed on BEI are more controlled by families. A survey conducted by the PWC in 2014 supported this finding and stated that more than $95 \%$ of businesses in Indonesia are family owned, and $60 \%$ of public companies (Tbk) in Southeast Asia are family companies.

Many cases of earnings management in Indonesia have been published by the Capital Market Supervisory Agency. For example, sales were inconsistently recorded by PT. Ades Alfindo, Tbk for 4 years from 2001 to 2004. Sulistiawan et al. (2009) stated that the reported amount of PT. Ades's sales was higher than the cost of production. In PT. Indofarma, Tbk, the presentation of inventory value was 
overstated in its 2001 financial statements. The result shows that the cost of production is low, so earnings are high. As such, the Capital Market Supervisory Agency implemented a sanction of Rp500 million to the directors of PT. Indofarma, Tbk. In the case of PT. Perusahaan Gas Negara, information about the decline in gas volume was concealed, thereby misleading investors. As a consequence, the company's stock price dropped from Rp9,650 to Rp7,400 per share. PT. Bank Lippo, Tbk issued two considerably different financial statements in 2002 especially in terms of the value of the foreclosed collateral, earnings and losses, asset values, and minimum capital liability ratio. PT. Kimia Farma, Tbk overstated earnings by increasing the value of finished goods inventory and sales value for their 2002 financial report. In these cases, the Capital Market Supervisory Agency also gave sanctions to the board of directors of PT. Kimia Farma, Tbk and KAP auditing company (Sulistiawan et al., 2009).

Earnings quality is considered high if it contains minimum to zero perception interference and is able to reflect the true performance of a firm (Gideon et al., 2018). Several studies on the effect of family ownership on earnings quality in accordance with the basic theory of agencies have shown mixed results. Wang (2006), Jung and Young (2002), Warfieid, Wild, Biggs, and Watts (1991), and Chen and Chen (2008) suggested that family companies show higher earnings quality because family companies have the advantage of disciplining and monitoring managers (Anderson dan Reeb, 2003), so managers act in accordance with the interest of shareholders (alignment). Yeo, Gillian, Tan, Patricia, Ho, Kim, and Sheng (2002), Beuselinck dan Manigart (2007), and Firth, Fung, and Rui (2007) implied that family-controlled companies have lower earnings quality. The existence of family-controlled ownerships likely promotes opportunistic behaviors, such as tunneling, of a majority of shareholders who can harm expropriate shareholders (Fan dan Wong, 2002).To hide this opportunistic behavior, a controller shareholder reports the lower quality of accounting information (Beuselinck and Manigart, 2007, Firth et al., 2007 and Aharony, Wang and Yuan, 2010). Prabowo (2013), Suyono (2016), and Diyanty (2017) found that several family companies in Indonesia implement earnings management.

Indonesia shares some common legal systems with continental European countries, such as Germany, Netherlands, and Italy. However, Indonesia has a different culture. Hofstede (2001) explained that Indonesians cooperate, maintain good relationships with others, show unwillingness to take risks, and exhibit conservativeness but remain open to changes. Another characteristic of family companies in Indonesia is that they tend to choose family members as part of the board of commissioners and directors (Wirawan dan Diyanty, 2014). The PWC study (2014) also indicated that the characteristics of family companies in Indonesia include maintaining family identity and prioritizing the company's long-term goals (i.e., maintaining family control and good family name) over business goals (obtaining company earning). This observation is consistent with the following SEW dimensions introduced by Berrone, Cruz, and Gomez-Mejia (2012): maintaining family control through shared ownership and placement of family members as directors and commissioners of the company and maintaining family generations.

\subsection{Hypothesis development}

Berrone et al. (2012) explained that one dimension of SEW is a succession of dynasties or generation to maintain family ties within a company. Westhead (2003) analyzed the motivation of family companies to maintain generations responsible for a given company. Assuming that the first generation or family founders have high family ties, Westhead (2003) found that the first generation of corporate control assumes that family priorities are more important than business objectives. Gils et al. (2004) also found that when the second or third generation takes control of the company, family priorities decrease.

In accordance with SEW theory, family companies prioritize SEW rather than business interests. Gomez-Mejia et al. (2007) stated that business owners unlikely take risks to keep SEW, but company 
owners take risks if SEW becomes threatened. Family companies controlled by the first generation prioritize family interests over other interests, such as maintaining a good family name. To achieve this initiative, they avoid taking risky actions that can damage it; for example, earnings management.

Conditions differ if the control of a family company has changed in succeeding generations. Arregle et al. (2007) and Gómez-Mejía et al., (2007) stated that the attachment of a family to its organization and family social capital likely decreases in the next generation. Under this condition, SEW, which has been a family's priority, becomes weak when its company has entered the next generation stage. As a result, nextgeneration families focus on business objectives so that risk preferences are the same as those of nonfamily investors (Schulze et al., 2003). Thus, family companies implement earnings management, although this technique possibly damages a family's good name. As such, family companies controlled by the first generation avoid earnings management to maintain family control, whereas the succeeding generations apply earnings management to maintain the company's business. Based on this explanation, the first hypothesis can be formulated as follows:

\section{H1: The first generation of family companies in Indonesia negatively affects earnings management.}

The role of BAPEPAM no. 29/PM/2004 explained that the members of the audit committee must have expertise or experience expertise in accounting and finance. A financial expert has knowledge of GAAP and financial statements, can access the accounting application of a firm, understands audit committee's tasks and functions, and has experience in auditing, preparing, analyzing, and evaluating financial reports. This position is in accordance with agency theory, which states that an owner or a shareholder cannot supervise the management behavior within a firm that tends to be opportunistic (Jensen \& Meckling, 1976). Therefore, monitoring mechanisms should be established to inform stakeholders that a firm's financial statements are correct (Defond et al., 2005). Krishnan \& Visvanathan (2008) argued that audit committee directors with expertise have the best ability to distinguish some accounting policies as conservative or aggressive and have more incentives than other directors.

In SEW theory, audit committees in family firms aim to compel the management to save the families' good name. Audit committees, which comprise experts in accounting, serve as a good corporate governance mechanism that minimizes the practice of earnings management by a family agent. Sherliza and Devi (2013) stated that audit committee is negatively correlated with earnings management. Inaam \& Khamoussi (2016)confirmed that audit committee negatively affects earnings management. Based on this explanation, the second hypothesis can be formulated as follows:

H2: An accounting expert of an audit committee negatively affects earnings management in family firms.

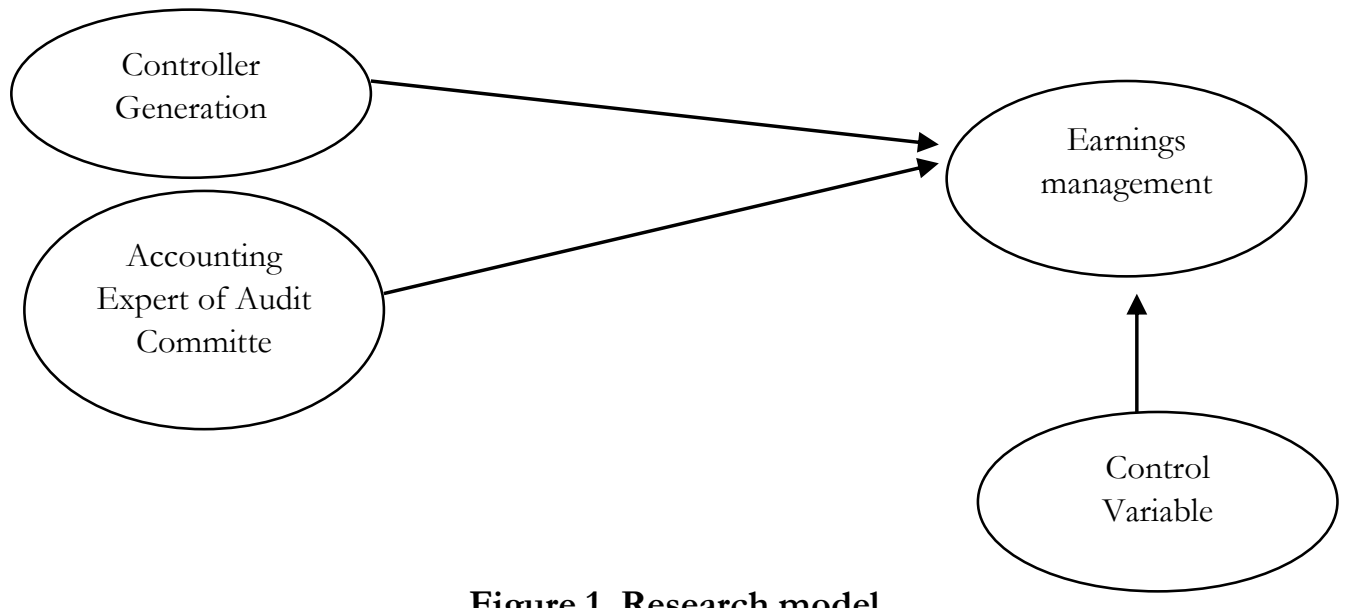

Figure 1. Research model 


\section{METHODOLOGY}

The population explored in this study consists of all manufacturing companies on the IDX because this type of industry is sufficient to contribute remarkably to the economy in Indonesia (Isniawati et al., 2018). The selection of family companies in this study used the same approach applied by Chua et al., (1999), who defined that a family company has a minimum of $25 \%$ shareholding by the family, has family members who hold positions as directors, and has a business vision held by all family members. On the basis of these criteria, we include 43 manufacturing companies in the category of family companies. We use the financial report data of 2012-2017 and obtain a total of 258 samples (i.e., 43 companies for 6 years).

Controller generation is defined as the generation of families who participate and influence the company in decision-making. Controller generation can be achieved through shareholding ownership (family ownership) and places family members in top management positions (family directors). This study adopts the controller generation proxy used by Stockman et al. (2010), who used dummy variable 1 for the first generation and 0 for the next generation. To determine the first generation or the next generation, they used the approach proposed by Prabowo dan Simpson (2011). In particular, the immediate owner's annual report should be initially presented, and company profile and various media sources should be subsequently searched to determine the generation of some family owners in a company. The accounting experts of the audit committee variable (AE) utilize the sum of the audit committee members who are experts in accounting divided by the total number of audit committee members.

The variable of earnings management in this research constitute the modified Jones model. The amount of earnings management measured using the value of discretionary accruals (DAC) is defined as the residual value of the equation below.

Note:

$$
\frac{T A_{i t}}{A_{i t-1}}=\alpha_{i}\left[\frac{1}{A_{i t-1}}\right]+\beta_{1 i}\left[\frac{\Delta R E V_{i t}-\Delta R E C_{i t}}{A_{i t-1}}\right]+\beta_{2 i}\left[\frac{P P E_{i t}}{A_{i t-1}}\right]+\varepsilon_{i t}
$$

TA

TA

$=$ total accruals in $\mathrm{t}$ year for $\mathrm{i}$ company

$N_{i t} \quad=$ net income in t year to i company

$\mathrm{CFO}_{\text {it }} \quad=$ cash flows in t year to i company

$\triangle R E V_{i t} \quad=$ revenues in $\mathrm{t}$ year to be diminished revenues of the previous year to $\mathrm{i}$ company

$P P E_{i t} \quad=$ gross property, plat, and equipment in t year to i company

$\triangle R E C_{i t} \quad=$ accounts receivables in $\mathrm{t}$ year to be diminished accounts receivables of the previous year to i company

$A_{i t-1} \quad=$ total assets of the previous year to i company

This study uses several control variables that regulates the influence of the main variable on the dependent variable, that is, company size as measured by the total assets Ln, leverage as measured by the leverage ratio or the debt-to-equity ratio, and earning ability as measured by net income. The model of this research is expressed as follows:

$$
\begin{gathered}
\mathrm{DAC}=\alpha+\beta 1 \text { Fam_Own }+\beta 2 \text { Fam_Dir }+\beta 3 \text { Control_Var }+\varepsilon \ldots \text { model } 1 \\
\mathrm{DAC}=\alpha+\beta 1 \text { Fam_Own }+\beta 2 \text { Fam_Dir }+\beta 2 \mathrm{AE}+\beta 3 \text { Control_Var }+\varepsilon \ldots \text { model} 2
\end{gathered}
$$




\section{EMPIRICAL RESULTS AND DISCUSSION}

\section{Descriptive statistics}

Table 1 shows the descriptive statistical data of each variable. The family ownership variable for 6 years has an average of 0.65 , indicating that $65 \%$ of family companies are still controlled by firstgeneration owners. The family director variable for 4 years has an average of 0.35 , indicating that $35 \%$ of family companies are still controlled by first-generation directors. The AE variable has a mean of 0.67 , suggesting that the audit committee has good experience in accounting. The variable of earnings management (DAC) is -0.06 .Thus, on average, family companies that enter the manufacturing industry in Indonesia have low earnings. For an average variable size of Rp487,221 billion, the averages of earning ability and leverage are Rp442,912 billion and 1.504,respectively.

Table 1

Descriptive Statistics

\begin{tabular}{|c|c|c|c|c|}
\hline & Mean & Min & Max & Standard Deviation \\
\hline Family Ownership & 0.65 & 0 & 1 & 0.390 \\
\hline Family Directors & 0.35 & 0 & 1 & 0.347 \\
\hline AE & 0.67 & 0.33 & 0.75 & 0.250 \\
\hline DAC & -0.06 & 0.01 & 2.68 & 0.154 \\
\hline Size & 28,779 & 132 & 487,221 & $256,06.1$ \\
\hline Earning & 442,912 & 0.012 & 751,295 & 88,545 \\
\hline Leverage & 1.504 & 0.013 & 31.781 & 2.910 \\
\hline
\end{tabular}

Size and Earning in billion rupiah.

\section{Findings}

The results of the regression test in Table 2 indicate that the coefficient of family ownership variable is -0.01 with a significant level of 0.01 , and the coefficient of family director variable is -0.47 with a significant level equal to 0.04 . Therefore, the controller generation through ownership and directors negatively affects earnings management. Thus, the first hypothesis is accepted. The results of this study support previous findings obtained by Stockmans et al. (2010), who suggested that the first generation in family companies reports quality earnings compared with the next generation because family attachment to organization and family social capital decline with the next generations. Consequently, succeeding generations focus on business objectives so that the same risk preference with nonfamily investors (Schulze et al., 2003) provides a high possibility of earnings management.

In Table 2 , the coefficient of the AE variable is -0.11 with a probability level of 0.06 .Considering that the significance level is less than $10 \%$, we can suggest that the accounting expert of the audit committee has a significantly negative effect on earnings management. Thus, the second hypothesis is accepted at the significance level of $10 \%$. This result supports previous findings obtained by Sherliza and Devi (2013) andInaam \& Khamoussi (2016), who stated that accounting experts of audit committees negatively influence earnings management. This finding is also supported by agency and SEW theories stating that the existence of an audit committee who has accounting skills reduces the possibility of an opportunistic manager in a firm to conduct earnings management. Therefore, an accounting expert of audit committees is important in businesses as a good corporate governance mechanism (Suprianto et al., 2017). We also examine whether the moderation variable AE*Fam_Own and AE*Fam_Dir affect earnings management. In Table 2, the moderation variable AE*Fam_Own significantly and negatively affects earnings management, whereas the moderation variable AE*Fam_Own and AE*Fam_Dir positively influences earnings management, but this effect is not significant. 
Table 2

Regression between independent variables of the Controllers Generation and Earnings Management

\begin{tabular}{|c|c|c|c|c|c|c|c|}
\hline \multirow[t]{2}{*}{$\begin{array}{l}\text { Independent } \\
\text { Variable }\end{array}$} & \multirow[t]{2}{*}{$\begin{array}{l}\text { Predict } \\
\text { Sign }\end{array}$} & \multicolumn{2}{|c|}{$\begin{array}{c}\text { Dependent } \\
\text { Variable } \\
\text { (DAC) }\end{array}$} & \multicolumn{2}{|c|}{$\begin{array}{l}\text { Dependent } \\
\text { Variable } \\
\text { (DAC) }\end{array}$} & \multicolumn{2}{|c|}{$\begin{array}{c}\text { Dependent } \\
\text { Variable } \\
\text { (DAC) }\end{array}$} \\
\hline & & $(\beta)$ & (Prob) & $(\beta)$ & (Prob) & $(\beta)$ & (Prob) \\
\hline Constant & $?$ & 2.53 & 0.05 & 1.90 & 0.25 & 1.33 & 0.07 \\
\hline FamOwn & - & -0.01 & 0.01 & -0.07 & 0.02 & -0.12 & 0.05 \\
\hline Fam_Dir & - & -0.47 & 0.04 & -0.30 & 0.03 & -0.21 & 0.05 \\
\hline $\mathrm{AE}$ & - & & & -0.11 & 0.06 & -0.07 & 0.01 \\
\hline AE*Fam_Own & - & & & & & -0.58 & 0.01 \\
\hline AE*Fam_Dir & - & & & & & -0.32 & 0.07 \\
\hline \multicolumn{8}{|c|}{ Control Variable: } \\
\hline Size & - & -0.59 & 0.06 & 0.86 & 0,00 & 0,03 & 0.05 \\
\hline Profitability & + & 0.13 & 0.00 & 0.20 & 0.04 & 0.10 & 0.00 \\
\hline Leverage & + & 0.65 & 0.00 & 0.70 & 0.00 & 0.06 & 0.07 \\
\hline \multicolumn{8}{|c|}{ Random Effect: } \\
\hline \multicolumn{2}{|c|}{ Total Obs. } & \multicolumn{2}{|c|}{258} & \multicolumn{2}{|c|}{258} & \multicolumn{2}{|c|}{258} \\
\hline \multicolumn{2}{|c|}{ R-Square } & \multicolumn{2}{|c|}{0.03} & \multicolumn{2}{|c|}{0.04} & \multicolumn{2}{|c|}{0.09} \\
\hline \multicolumn{2}{|c|}{$\begin{array}{l}\text { Wald Chi }^{2} \\
\text { Probability }\end{array}$} & \multicolumn{2}{|c|}{$\begin{array}{l}16.33 \\
0.00\end{array}$} & \multicolumn{2}{|c|}{$\begin{array}{c}20.02 \\
0.00\end{array}$} & \multicolumn{2}{|c|}{$\begin{array}{c}25.01 \\
0.00\end{array}$} \\
\hline
\end{tabular}

\section{Discussion}

Our results are consistent with the predictions of SEW theory stating that family companies unlikely take risks to maintain SEW (Gomez-Mejia et al., 2007). Family companies controlled by the first generation prioritize family interests over other interests, such as maintaining the good name of their family. As such, they avoid risky actions that can damage their family name. For example, earnings management.

To support this result, we conduct robustness testing by subjecting the earnings management behavior of each group of family companies to trend analysis. In this analysis, family companies are divided into four groups. Group 1 is a family company group owned by the first generation and has a second-generation president director. Figure 2 shows that this group individually performs varying earnings management but appears stable from -0.04 to -0.06 as indicated by the linear trend. Therefore, the existence of first-generation owners likely prevents the second-generation managers from implementing earnings management. The same condition is also illustrated in Figure 3 that is, Group 2 comprises family companies owned and managed by the first generation. Its linear trend is stable from 0.01 to 0.02 .

Group 4 includes family companies owned and managed by the second generation. In Figure 4, this group individually varies in earnings management (Figures 2 and 3).Conversely, its linear trend decreases significantly between -0.14 and -0.02 . Thus, second-generation owners and managers likely perform earnings management. These results support a previously tested hypothesis.

\section{CONCLUSION}

On the basis of the results of our analysis, we conclude that the controller generation negatively affects earnings management. Thus, the hypothesis is accepted. The results of this study disagree with previous findings obtained by Schulze et al. (2003), Stockmans et al. (2010), and Gómez-Mejía et al., (2007) and are supported by the trend analysis in Group 1, which is owned by the first-generation family 
and includes the second-generation director, and Group 2, which comprises the family company owned and managed by the first generation. The linear trend appears stable from 0 to 0.01 . In Group 3, which consists of the family company owned and managed by the second generation, the linear trend drops significantly between 0.2 and -0.2 . Accounting experts of the audit committee also negatively affect earnings management. This study has several limitations. First, the sample of this study is limited to the manufacturing industry, so this result can be generalized to this industry only. Further research should be performed to analyze other industries. Second, earnings management measures are derived from an accrual approach. Further research should be conducted to examine real earnings management and obtain accurate results.

\section{ACKNOWLEDGMENT}

The authors are thankful to Lembaga Pengelola Dana Pendidikan (LPDP), Ministry of Finance of Republic of Indonesia, for funding this research.

\section{REFERENCES}

Abbott, L. J., Parker, S., \& Peters, G. F. (2004). Audit committee characteristics and restatements. Auditing: A Journal of Practice \& Theory, 23(1), 69-87.

Achleitner, A., Günther, N., \& Kaserer, C. (2014). Real Earning management and Accrual-based Earning management in Family Companys. European Accounting Review, 23(3), 431-461.

Assih, P., \& Hastuti, A. W. (2014). Pengaruh manajemen laba pada nilai dan kinerja perusahaan. Jurnal Akuntansi dan Keuangan Indonesia, 2(2), 125-144.

Berrone, P., Cruz, C., \& Gomez-Mejia, L. R. (2012). Socioemotional wealth in family firms: Theoretical dimensions, assessment approaches, and agenda for future research. Family Business Review, 25(3), 258-279.

Carney, R. W., \& Child, T. B. (2013). Changes to the ownership and control of East Asian corporations between 1996 and 2008: The primacy of politics. Journal of Financial Economics, 107(2), 494-513.

Cennamo, C., Berrone, P., Cruz, C., \& Gomez-Mejia, L. R. (2012). Socioemotional wealth and proactive stakeholder engagement: Why family-controlled firms care more about their stakeholders. Entrepreneurship Theory and Practice, 36(6), 1153-1173.

Artikis, G. P., Chalevas, C., \& Tzovas, C. (2010). The effect of the mandatory adoption of corporate governance mechanisms on earnings manipulation, management effectiveness and firm financing. Managerial Finance, 36(3), pp.257-277.

Chandar, N., Chang, H., \& Zheng, X. (2012). Does overlapping membership on audit and compensation committees improve a firm's financial reporting quality?. Review of Accounting and Finance, 11(2), 141-165.

Chen, K. Y., Elder, R. J., \& Hsieh, Y. M. (2007). Corporate governance and earnings management: The implications of corporate governance best-practice principles for Taiwanese listed companies. Journal of Contemporary Accounting \& Economics, 3(2), 73-105.

Chua, J. H., Chrisman, J. J., \& Sharma, P. (1999). Defining the family business by behavior. Entrepreneurship theory and practice, 23(4), 19-39.

Claessens, S., Djankov, S., \& Lang, L. H. (2000). The separation of ownership and control in East Asian corporations. Journal of Financial Economics, 58(1-2), 81-112.

Cornett, M. M., Marcus, A. J., \& Tehranian, H. (2008). Corporate governance and pay-for-performance: The impact of earnings management. Journal of Financial Economics, 87(2), 357-373.

Davis, P. S., \& Harveston, P. D. (1999). In the founder's shadow: Conflict in the family firm. Family Business Review, 12(4), 311-323.

DeFond, M. L., \& Jiambalvo, J. (1994). Debt covenant violation and manipulation of accruals. Journal of Accounting and Economics, 17(1-2), 145-176.

Diyanty, V. (2016). Does the pyramidal ownership mechanism negatively affect the firm's performance?. Journal of Economics, Business \& Accountancy Ventura (JEBAV), 19(2), 205-218. 
Ensley, M.D. \& Pearson, A.W., 2005. An Exploratory Comparison of the Behavioral Dynamics of Top Management Teams in Family and Nonfamily New Venture: Cohesion, Conflict, Potensy, and Consensus. Entrepreneourship Theory and Practice, 267-284.

Gideon, B. D., Puspitasari, E., Ghani, E. K., \&Gunardi, A. (2018). Earnings Quality: Does "Principles Standards versus Rules Standards" Matter? Journal of Applied Economic Sciences, 13(2), 586-596.

Gils, A.V.A.N., Voordeckers, W. \& Heuvel, J.V., 2004. Environmental Uncertainty and Strategic Behavior in Belgian Family Companys. European Management Journal, 22(5), 588-590.

Gomez-mejia, L.R. et al., 2007. Socioemotional Wealth and Business Risks in Family-controlled Companys: Evidence from Spanish Olive Oil Mills. Administrative Science Quarterly, 52, 106-137.

Habib, A., Haris, A. \& Jiang, H., 2017. Political Connections and Related Party Transactions : Evidence from Indonesia. International Journal of Accounting, 1-19.

Healy, P.M., 1985. The Effect of Bonus Schemes on Accounting Decisions, 7, 85-107.

Isniawati, A., Rahmawati, R., \&Gunardi, A. (2018). Information Asymmetry and Accounting Conservatism: Does Analyst Coverage Moderate the Results? Journal of International Studies, 11(3), 176-190.

Jones, J.J., 1991. Earning management During Import Relief Investigations. Journal of Accounting Research, 29(2), 193-228.

Kusuma, H. \& Sari, W.A.U., 2003. Manajemen Laba Oleh Perusahaan Pengakuisisi Sebelum Merger Dan Akuisisi Di Indonesia. Jurnal Akuntansi \& Auditing Indonesia, 7(1), 21-36.

Krishnan, G. V \& Visvanathan, G., 2008. Does the SOX Definition of an Accounting Expert Matter? The Association between Audit Committee Directors' Accounting Expertise and Accounting Conservatism *. Contemporary Accounting Reserach, 25(3), 827-857

Masripah, Diyanty, V. \& Fitriasari, D., 1999. Controlling Shareholder and Tax Avoidance : Family Ownership and Corporate Governance. International Research Journal of Business Studies, 8(3), 167-180.

Muawanah, U., 2014. Corporate governance Dan Kepemilikan Keluarga. Jurnal Akuntansi Multiparadigma, 5(2), 287-298.

Mulyani, E., Singh, H. \& Mishra, S., 2016. Dividends, Leverage, and Family Ownership in the Emerging Indonesian Market. Journal of International Financial Markets, Institutions \& Money".

Noronha, C., Zeng, Y. \&Vinten, G., 2008. Earning management in China : an exploratory study. Managerial Auditing Journal, 23(4), 367-385.

Paiva, I.S., Lourenco, I.C. \& Branco, M.C., 2016. Earning management in family companys : current state of knowledge and opportunities for future research. Review of Accounting and Finance, 15(1), 85-100.

Pazzaglia, F. et al., 2013. Earning Quality in Acquired and Nonacquired Family Companys : A. Family Business Review, 26(4), 374-386.

Porta, R. LA et al., 2002. Investor Protection and Corporate Valuation. The Journal of Finance, 57(3), 1147-1170.

Prabowo, M.A., 2013. Performance Of Family-Controlled Banks: Do Political Connections Matter? Jurnal Akuntansi \& Auditing Indonesia, 17(2), 115-122.

PWC., 2014. Survey BisnisKeluarga 2014.

Schulze, W.S., Lubatkin, M.H. \& Dino, R.N., 2003. Toward a theory of agency and altruism in family companys. Journal of Business Venturing, 18, 473-490.

Sevin, S. et al., 2005. Earning management: evidence from SFAS No. 142 reporting. Managerial Auditing Journal, 20(1), 47-54.

Siregar, S.V. \& Utama, S., 2008. Type of earning management and the effect of ownership structure, company size, and corporate-governance practices : Evidence from Indonesia. The International Journal of Accounting, 43, $1-27$.

Stockmans, A., Lybaert, N. \&Voordeckers, W., 2010. Socioemotional Wealth and Earning management in Private Family Companys. Family Business Review, 23(3), 280-294.

Sulistiawan, D., Januarsih, Y. \&Alvia, L., 2009. Creative Accounting: Mengungkap Manajemen Laba dan Skandal Akuntansi, 
Suprianto, E., Suwarno, S., Murtini, H., Rahmawati, R., \& Sawitri, D. (2017). Audit Committee Accounting Expert and Earnings Management with "Status" Audit Committee as Moderating Variable. Indonesian Journal of Sustainability Accounting and Management, 1(2), 49-58. http://doi.org/10.28992/ijsam.v1i2.16

Suyono, E., 2016. Family controlled company, governance mechanisms and corporate performance : Evidence from Indonesia. Journal of Economics, Business, and Accountancy Ventura, 19(1), 111-124.

Undang-Undang nomor 40 tahun 2007 tentang Perseroan Terbatas

Veronica, S. \& Bachtiar, Y.S., 2005. Corporate Governance, Informastion Asymetry and Earning management. JurnalAkuntansi dan Keuangan Indonesia, 2(1), 77-106.

Warfieid, T.D. et al., 1991. Managerial ownership, accounting choices, and informativeness of earning. Journal of Accounting and Economics, 20, 61-91.

Westhead, P., 2003. Company performance and objectives reported by first and family companies : a research note. Journal of Small Business and Enterprise Development, 10(1), 93-105.

Widyaningsih, I. U., Gunardi, A., Rossi, M., \&Rahmawati, R. (2017). Expropriation by the Controlling Shareholders on Firm Value in the Context of Indonesia: Corporate Governance as Moderating Variable. International Journal of Managerial and Financial Accounting, 9(4), 322-337. http://doi.org/10.1504/IJMFA.2017.10009973

Wirawan, B. \& Diyanty, V., 2014. Kepemilikan keluarga, hubungan politik dan Family Aligned Board Terhadap Implementasi Tata Kelola Perusahaan. Jurnal Akuntansi \& Auditing Indonesia, 18(2), 139-155.

Wulandari, E.R., 2004. Good Corporate Governance (Konsep, Prinsip dan Praktik),

Zhu, T. et al., 2015. Accrual-based and real activity earning management at the back door : Evidence from Chinese reverse mergers. Pacific-Basin Finance Journal, 35(12), 317-339. 


\section{APPENDIXES}

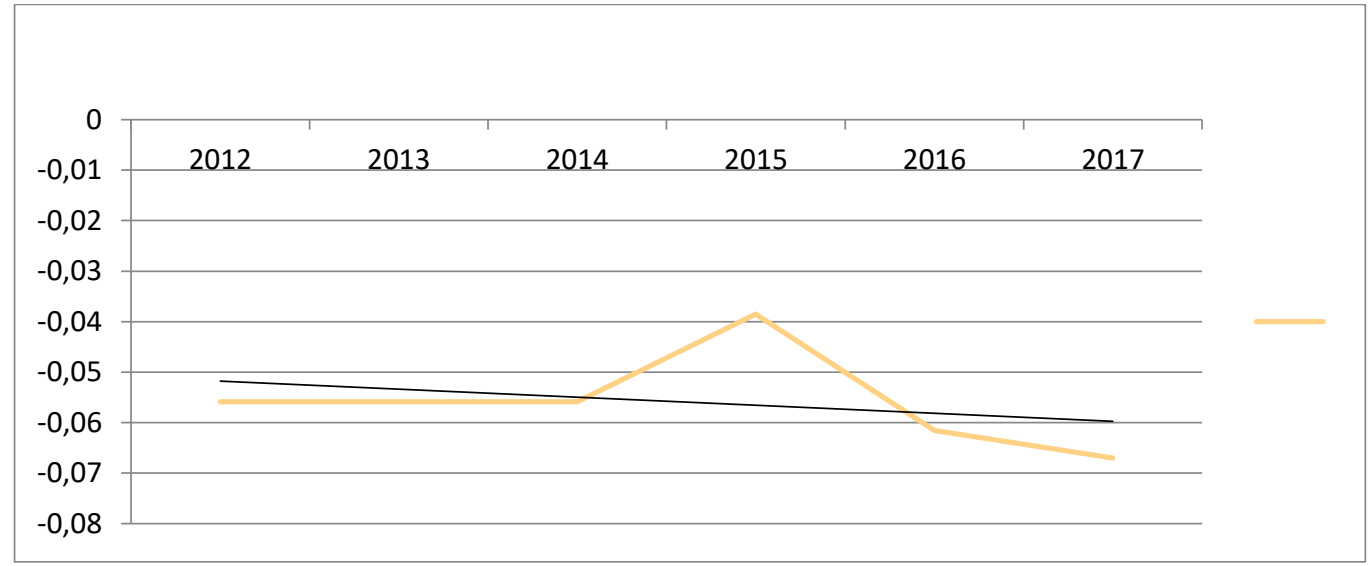

Figure 2. Earnings management of the Family Company

Owner (first generation) and the President Director (second generation)

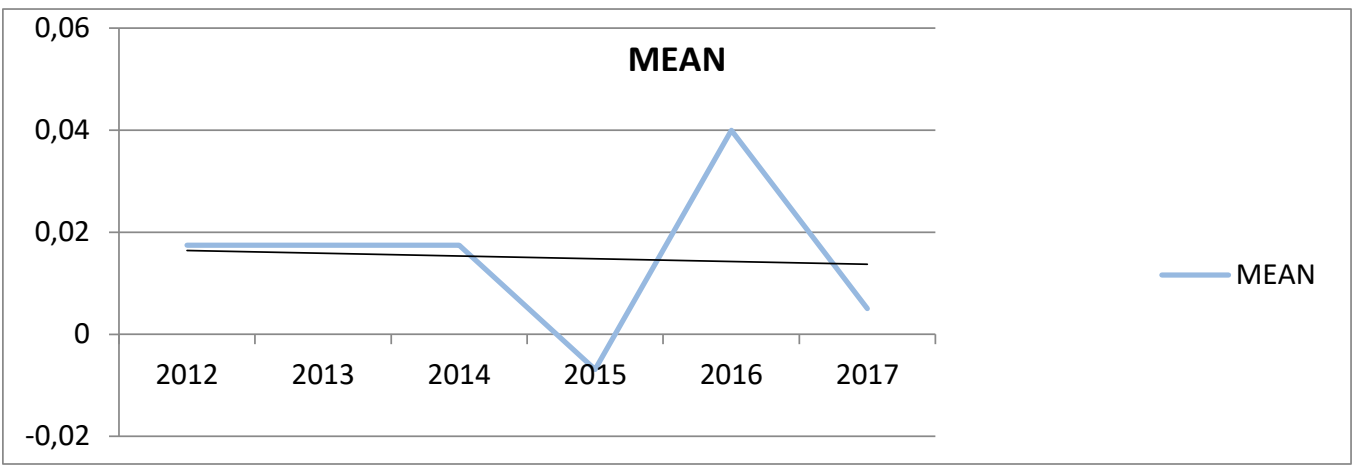

Figure 3. Earnings Management of the Family Company Owner and President Director (first generation)

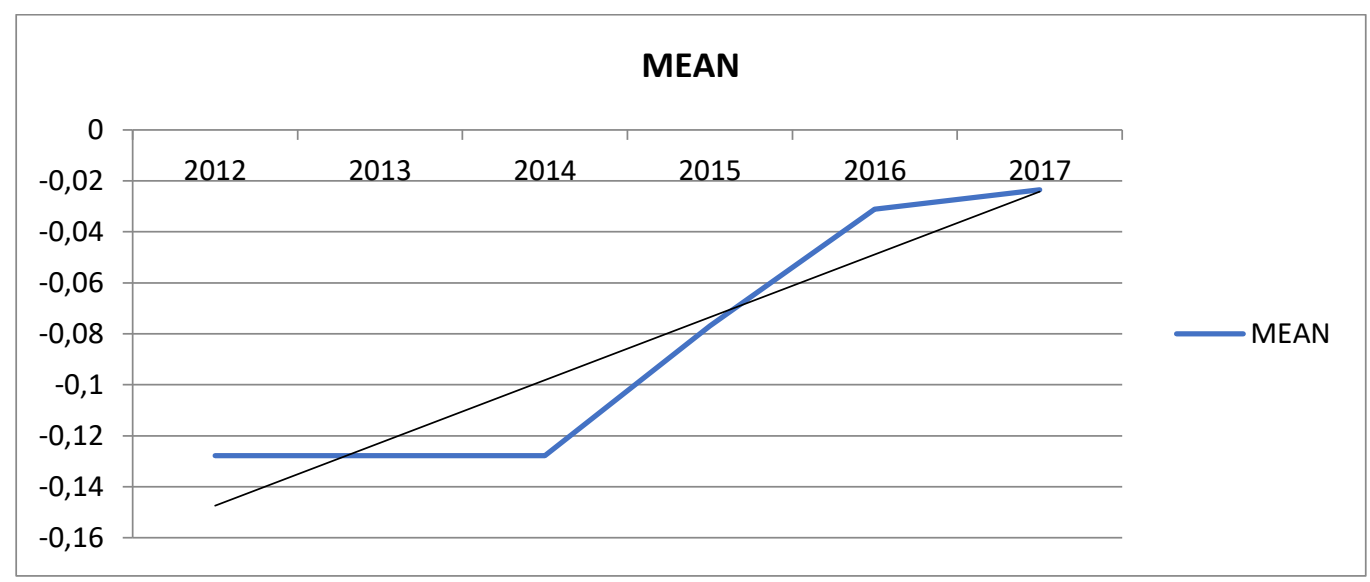

Figure 4. Earnings Management of the Family Company

Owner and President Director (second generation) 